\title{
Managing Sustainable Microfinance Institutions In The Covid-19 Situation Through Revitalizing Balinese Cultural Identity
}

\section{Putu ASTAWA ${ }^{1 *}$, I Wayan Wesna ASTARA ${ }^{2}$, I Gede MUDANA ${ }^{3}$, Christantius DWIATMADJA ${ }^{4}$}

\author{
1Satate Polytechnic of Bali, Bali, Indonesia, Email: putuastawa1@pnb.ac.id \\ ${ }^{2}$ Warmadewa University,Bali, Indonesia ,Email: wesna_astara@yahoo.com \\ ${ }^{3}$ Satate Polytechnic of Bali, Bali, Indonesia, Email: gedemudana@pnb.ac.id \\ ${ }^{4}$ Kristen SatyaWacana University, Indonesia, Email: christantius.dwiatmadja@staff.uksw.edu \\ ${ }^{*}$ Corresponding Author
}

\author{
Received: 03.05.2021 \\ Accepted: 24.07.2021 Published: 18.10.2021 \\ DOI: 10.47750/QAS/22.184.17
}

\begin{abstract}
Managing microfinance institutions in Bali, Indonesia, is very dependent on the philosophy of culture of harmony as a guide for people to live in harmony with other people and the environment around them. This basis makes microfinance institutions stronger compared to other microfinance institutions in Indonesia. However, the current COVID-19 pandemic situation has paralyzed Bali's economy, prompting company leaders to look inward and outward to keep the business running sustainably. The main purpose of this study is to analyze a comprehensive and broader view of how companies identify the drive for sustainability without eliminating practices and values that are following the culture of the Balinese people of Indonesia. Experimental data were obtained from native Balinese as influential corporate leaders and executive agencies. The results show that responsive leadership is the leading force in dealing with the Covid-19 problem from an internal approach. On the other hand, from an external point of view, the main determining factor is the difference in the company's ability to make it difficult for the government to handle problems. This research combines both companies with internal and external motivations for sustainability and how cultural values influence sustainability drives. This is based on cultural identity having a strategic role in microfinance institutions in Bali. Therefore steps are needed to revitalize a culture of harmony related to strategy formulation and implementation in microfinance institutions to gain competitive advantage and organizational performance.
\end{abstract}

Keywords: Culture; harmony, microfinance, sustainable company, Covid-19

\section{Introduction}

It's like being struck by lightning economic conditions and equated with economic conditions during the Second World War (Tempo, 2020) when the current COVID-19 occurred. WHO declared the COVID-19 outbreak a global emergency on January 30th, 2020 (Khan \& Yu, 2020). The government responded to this incident to impose lockdowns, travel restrictions, and quarantines (Barney, 1991; Mahoney, et al. 1992) in several countries worldwide and sparked fears of an imminent economic crisis (Pitelis, 2007). COVID-19 has affected society, businesses, and organizations globally, unintentionally affecting financial markets and the economy. The government's uncoordinated response and lockdowns are causing disruptions in the supply chain. In China, lockdown restrictions have significantly reduced the production of goods from factories, while quarantine and self-isolation policies have reduced consumption, demand, and utilization of products and services (Porter, 1985).

In the United States (US), the stock market index as a tool to measure the stock performance of the 500 large companies on the US Stock Exchange, the Dow Jones Industrial Average, and the NASDAQ fell dramatically until the US government secured it through legal aid, relief, and economic security (CARES), with an increase in the index of $7.3 \%, 7.73 \%$, and $7.33 \%$, respectively (Stonehouse \& Snowdon, 2007; Creswell \& Clarck, 2017; Yuan, et al. 2018; Astawa, et al. 2019). The decline in global stock markets has hampered the performance of companies with critical liquidity levels (Bracalente, et al. 2011). To combat this effect, several countries, such as Indonesia, through Bank Indonesia, have intervened to ensure liquidity is maintained and reduce shocks in economic spending outside of handling COVID-19, so various approaches are needed (Pitelis, 2007; Buckley, 2012). The policies of the Indonesian government include easing electricity costs, bans on going home, large-scale social restrictions, credit relief, and providing assistance amounting to 405.1 trillion (Kompas, 2020).

Banks have a high sensitivity to economic downturns because there is a possibility of bad debts (Bongini et al., 2019). The same is true for microfinance institutions, which mainly serve the lower middle class. The poor feel pressured during this pandemic, mostly from loans from microfinance institutions 
(MFIs) (Noreen, 2020). This condition pressures MFI managers to change management related to cost-effectiveness, ecology, society (Van der Berg et al., 2019; Akhtar, 2019; Bartok, 2018) and affects business operations (Manning \& Reimsbach, 2019). One of the thoughts is how to maintain business sustainability in this challenging situation. Many problems arise when companies bring various sustainability attributes into the organizational framework (Rajiani \& Kot, 2018; Wróblewski \& Dacko-Pikiewicz, 2018). Therefore, various multi-dimensional issues as an approach support company sustainability which depends on triggering technology and administrative experience. The condition that often occurs is the tendency to ignore the economic, social, cultural, environmental, time and interaction elements between them which are elements of sustainability. (Sukawati et al. 2020; Astawa et al. 2020; Lozano, 2019). Currently, Corporate Sustainability (CS) has become an effective way to run a business (Das et al., 2020) and has become an obligation for companies. (Ashrafi et al., 2020). Therefore, to change to favor sustainability, the company must embrace change that combines advances in high technology, managing business plans, and providing quality services (Demirel \& Kesidou (2019)

Bali in Indonesia is a small island that has become a tourist destination with a harmonious Hindu-based cultural identity. The culture of harmony, also called the Tri Hita Karana (THK) culture, has a philosophy that prosperity will only be achieved through a harmonious relationship between individuals and nature (Palemahan); the relationship between humans themselves (pawongan); and the relationship between man and God (Parahyangan). The results of previous studies in Bali have shown the strong influence of THK on strategic objectives and the importance of culture for the realization of strategic objectives (Astawa et al. 2020; Rahmawati et al., 2019). Microfinance institutions in Bali that serve rural communities known as village credit institutions (LPD) totaling 1436 (Radar Bali, 2020) have struggled with cost-effectiveness and profitability. Since the development of microfinance institutions worldwide is pro-poor, especially in Bali, competition is getting more challenging to get enough customers (Cong, 2020). LPD seeks to preserve its dominant position in the village in a competitive market by taking advantage of various competitive advantages. Based on the results of previous research, this research was expanded in the form of a qualitative case study with LPD stakeholders to focus on the role of businesses inspired by culture in Bali and how they see the drivers of company sustainability amid COVID-19.

\section{Literature Review}

Companies that adhere to sustainable understanding will actively support and maintain a balance in sustainability, including financial, natural environment, and socio-cultura issues. This element is related to the company's journey in building a framework regarding tasks, innovation, administration, assessment, and relationships with business partners (LOZANO, 2019, Wakimin et al., 2019). Several research results have explained that companies that carry the concept of sustainability do not only emphasize raw materials, procedures, resources, and several production attributes (Schönborn et al., 2019; Soderstrom \& Weber, 2020). However, currently, the company's sustainability places a lot of emphasis on the values of the company (Reicher, 2019). This is also related to the company's behavior and corporate culture in solving nonmechanical problems. Therefore, hierarchical changes in supporting sustainability must go through a comprehensive process from top to bottom leadership elements to realize innovation through cultural change. (Obal et al., 2020; Civelek et

\section{al., 2019).}

When the company implements a cultural change, many things need to be adjusted, such as adjustments in the hearts, thoughts, words, and actions of all members of the company is an obligation. This cultural change made into company regulations takes a long time and goes through several stages of karma and aptitude (Tian \& Christensen, 2020). Corporate sustainability also requires sweeping management changes, including subtle things such as mental models, changes in the hierarchy, implementation of innovations, and comparisons of ways of working in supporting the achievement of progress (Thakur \& Mangla, 2019).

The company's sustainability arises because there are external pressures and internal pressures. Companies that adhere to the notion of sustainability emphasize the progress of the national economy to increase state revenues (Zhulega et al., 2019). External factors raise debates to support sustainability, while internal factors are more proactive in supporting sustainability (Broccardo et al., 2019). External triggers come from the government and stakeholders (Zahid et al., 2019; Plaček et al., 2019). Based on this view, all company members must thoroughly understand all internal elements and processes (Álvarez et al., 2019). One of the internal triggers is the leadership ethics needed to change progress (Jovchelovitch, 2019). However, companies cannot rely on changes made by leaders alone, but many factors must be considered, such as risk management, business scope (Noreen, 2020; Schaltegger \& Burritt, 2018), economic value (Garry \& Harwood, 2017), and enhancements needed to explain the company (Chong, 2020).

Some of the reasons companies run sustainability are caused by internal factors such as Responsive leadership; Business reports; Precautionary rules; Company's way of life; Moral commitment to CS; Sustainability reports; Avoiding hazards; Sustainability agent of change; Demands from representatives on organizations CS endeavors; and Economic concerns (Sukawati et al. 2020; Astawa et al. 2020; Chong, 2020; Schaltegger \& Burritt, 2018). Other reasons related to external factors are reputation, for example, corporate or brand distinctive positioning; Customer requests and desires; Regulation and enactment; Society's raising mindfulness; Access to assets; Collaboration with third parties; Negative exposure; protest NGOs; Environmental or social emergencies: National or territorial conditions; Market openings; market positioning; Shareholder activism; Peer-pressure; Market requests for non-budgetary data (Sukawati et al. 2020; Astawa et al. 2020; Chong, 2020; Schaltegger \& Burritt, 2018; Garry \& Harwood, 2017).

Culture influences management practices (Rajiani \& Pyplacz, 2018). The core element in culture is valued, which tends to prefer one's country of affairs. They are about evil vs. good; dirty vs. clean; immoral vs. moral, and irrational vs. rational. The relationship between humans in a society is always influenced by values that are part of the cooperative program of the community's mind (Hofstede, 2007; Ranasinghe, 2019; Wróblewski \& Kasperek, 2019). In Bali, the foundation of shared beliefs and values is the tri hita karana (THK) cultural philosophy that transcends all aspects of life, including business and governance. THK's philosophy greatly influences the values, attitudes, and social norms in the Balinese tourism system, and the deep connection with the natural environment is deeply rooted in this belief system. (Rahmawati et al., 2019; Sukawati \& Astawa, 2017). With this analogy, the management of Bali is assumed to practice harmonious elements in managing the business for sustainability. However, this notion raises new problems: Does Balinese Indonesians' exclusive cultural identity make them competitive and adaptive to the business environment? How do business practitioners rate its effectiveness? This question calls for the refinement of theory 
and developing a more comprehensive theoretical model, especially in Balinese culture. This unexplored issue is the focus of this study.

\section{Materials and Methods}

Qualitative methods are used in this research to collect data. It can provide in-depth information about the situation and interpret the understanding and experience of the person in which the person is being studied (Ritchie et al., 2013). In addition, this paradigm provides a set of interpretive practices. Ten people were interviewed in a semi-structured manner. There are three types of respondents identified: conceptors, implementers, and beneficiaries. Three criteria were used to determine the appropriate respondents; (1) high knowledge in Balinese philosophy; (2) involvement in the management of the Village Credit Institution (LPD); (3) and experience in practicing THK philosophy. After rigorous screening, the drafters consisted of a chief executive officer of one of the most famous LPDs integrating the THK concept, which is located in Kedonganan Village, South Kuta. Four professors of management from Udayana University Bali, and one high-ranking official in the provincial government who formulated Bali island policies, were added to validate the THK concept. Furthermore, three LPD managers in Bali applying the THK concept in management were selected as implementers. The beneficiary was one village head who experienced LPD operational benefits when implementing the THK idea. The ten interviewees were identified as R1, R2, R3, R4, R5, R6, R7, R8, R9, and R10. Interviews were conducted from March 2020 to August 2020. The application of qualitative studies can reveal things that were not explored in the theoretical background (Sampson \& Johannessen, 2020). Research questions were addressed to critical leaders to obtain answers about: how companies can achieve sustainability achievements; and how can key leaders detect, manage and evaluate strengths for sustainability? As Jovchelovitch (2019) says, executives/key leaders in groups or companies can be the most reliable informants. A voice recorder was used during the interview, and then the data was transcribed. Each meeting lasts approximately one to two hours. The data were then analyzed using a thematic approach. Two critical challenges emerged based on interviewees' responses, which included reasons from within and outside the organization to engage in corporate sustainability.

\section{Results and discussion}

The results of in-depth interviews with key informants can be explained in Table 1.

\begin{tabular}{|c|c|c|}
\hline Informant & Answers & Conclusion \\
\hline R1 & $\begin{array}{l}\text { Ability to pay attention to the company's internal and external } \\
\text { strengths. This can be seen from internal aspects such as responsive } \\
\text { leadership and various rules for prevention. }\end{array}$ & $\begin{array}{l}\text { Internal and external; } \\
\text { Responsive leadership; } \\
\text { Precautionary rules }\end{array}$ \\
\hline $\mathrm{R} 2$ & $\begin{array}{l}\text { Companies must realize that internal and external strengths will have } \\
\text { an impact on the company's sustainability. Externally the excellent } \\
\text { name of the company is taken into consideration. }\end{array}$ & $\begin{array}{l}\text { Internal and external; } \\
\text { Troubleshooting method; } \\
\text { Company commitment; } \\
\text { Reputation }\end{array}$ \\
\hline R3 & $\begin{array}{l}\text { Internal and internal strengths are the focus of the company that must } \\
\text { be considered. External forces relate to consumer demand and } \\
\text { government regulations. We can do this internally by prioritizing } \\
\text { prudence in avoiding bankruptcy. }\end{array}$ & $\begin{array}{lr}\text { Internal and } & \text { external; } \\
\text { Consumer } & \text { demand; } \\
\text { Government } & \text { regulations; } \\
\text { Avoid danger } & \\
\end{array}$ \\
\hline $\mathrm{R} 4$ & $\begin{array}{l}\text { We view internal and external strengths as inseparable in maintaining } \\
\text { the company's sustainability. We need a sustainability report that we } \\
\text { must make, and we are aware that we are agents of change in } \\
\text { business activities. }\end{array}$ & $\begin{array}{l}\text { Internal and external; } \\
\text { Sustainability report; Agent } \\
\text { of change }\end{array}$ \\
\hline R5 & $\begin{array}{l}\text { I strongly agree that the company's strength rests on its internal and } \\
\text { external strengths. Still, internally we are also required to continue } \\
\text { maintaining business sustainability through the company's } \\
\text { representative councils. }\end{array}$ & $\begin{array}{l}\text { Internal and external; } \\
\text { demands from company } \\
\text { representatives }\end{array}$ \\
\hline $\mathrm{R} 6$ & $\begin{array}{l}\text { Inevitably internal and external forces are required, and economic } \\
\text { concerns must be considered. }\end{array}$ & $\begin{array}{l}\text { Internal and external; and } \\
\text { economic concerns }\end{array}$ \\
\hline R7 & $\begin{array}{l}\text { The concept of sustainability is influenced internally and externally } \\
\text { and, most importantly, externally related to people's attention to the } \\
\text { company. }\end{array}$ & $\begin{array}{l}\text { Internal and external; public } \\
\text { attention continues to } \\
\text { increase }\end{array}$ \\
\hline R8 & $\begin{array}{l}\text { Internal and external conditions become a barometer in implementing } \\
\text { corporate sustainability by involving existing cultural values. Various } \\
\text { regulations often bother us. }\end{array}$ & $\begin{array}{l}\text { Internal and external; local } \\
\text { culture; } \\
\text { regulation }\end{array}$ \\
\hline $\mathrm{R} 9$ & $\begin{array}{l}\text { Internal and external are the primary targets for us to observe and the } \\
\text { moral strength to commit to sustainability. }\end{array}$ & $\begin{array}{l}\text { Internal and external; moral } \\
\text { commitment }\end{array}$ \\
\hline $\mathrm{R} 10$ & $\begin{array}{l}\text { It is better to pay attention to the internal and external strengths owned } \\
\text { and need to do regular reports. }\end{array}$ & $\begin{array}{l}\text { Internal and external; } \\
\text { sustainability report }\end{array}$ \\
\hline
\end{tabular}

Table 1: Interview results

Source: Processed Data (2020)

In Table 1, it is explained that everyone interviewed agreed that the trigger came from external and internal. They provide a view where most of them view leadership as the primary internal reason. Other internal reasons determined by the informant were preventive measures, the company's way of life, ethical and moral cases, avoiding a hazard, employee point of view, on 
agents of corporate sustainability change, and economic concerns. The most frequently mentioned reasons for extraordinary that the respondents emphasized were reputation; customer requests and desires; regulation and enforcement, and increasing public awareness. The interviewers then classified all the triggers into the Tri Hita Karana (THK) philosophy in table 2, which integrates the relationship between people and the environment (Palemahan); people and people (Pawongan), as well as people and Creators (Parahyangan).

\begin{tabular}{|c|c|}
\hline Reasons & Tri Hita Karana (THK) \\
\hline $\begin{array}{l}\text { Internal reasons } \\
\text { - Responsive leadership } \\
\text { - } \text { Precautionary rules } \\
\text { - } \text { Mompany way of life } \\
\text { - Sustainability report } \\
\text { - Avoiding danger } \\
\text { - Agents of sustainability change } \\
\text { - Demands from representatives about the } \\
\text { - } \text { Economization's CS efforts }\end{array}$ & $\begin{array}{ll}\text { - } & \text { Parahyangan (Creator) } \\
\text { - } & \text { Parahyangan (Creator) } \\
\text { - } & \text { Pawongan (people) } \\
\text { - } & \text { Palemahan (environment) } \\
\text { - } & \text { Palemahan (environment) } \\
\text { - } & \text { Palemahan (environment) } \\
\text { - } & \text { Pawongan (people) } \\
\text { - } & \text { Pawongan (people) }\end{array}$ \\
\hline $\begin{array}{ll}\text { External reasons } \\
\text { - } \\
\text { - } \text { Reputation, e.g., distinctive company or brand } \\
\text { - } \text { Customer requests and wishes } \\
\text { - } \text { Regulation and enforcement } \\
\text { - Local culture }\end{array}$ & $\begin{array}{ll}\text { - } & \text { Parahyangan (Creator) } \\
\text { - } & \text { Pawongan (people) } \\
\text { - } & \text { Pawongan (people) } \\
\text { - } & \text { Palemahan (environment) } \\
\text { - } & \text { Pawongan (people) }\end{array}$ \\
\hline
\end{tabular}

Table 2: Inner and outer reasons in Tri Hita Karana

\section{Source: Processed Data (2020)}

The results of this study provide a clear view of the results of previous research (Joseph et al., 2019) that leadership is the main motive in corporate sustainability. Leadership is important for several reasons, as some of the interviewees currently hold strategic positions. As R1 said: When a leader maintains harmony between the three relationships of the creator, people, and environment, prosperity will be achieved. In the implementation of business activities, Respondents 2, 3 stated: The parahyangan concept is applied with the prostration of devotion through giving offerings to God. Business activities are not only focused on maximizing profits but also a form of awareness of the hereafter. Every business activity carried out is primarily controlled by God.

Similarly, in applying the concept of pawongan, leaders are creatures, creatures of God like any other. This business is also expected to create a balanced relationship with the environment. Maintaining harmony or balance is done by not exploiting the environment excessively not to endanger business continuity in the future. This should always be the first consideration when executing a business strategy.

This cosmological philosophy of life has proven to be an important concept that has preserved the sustainability of Bali's diverse culture and environment and the peaceful life among people of different backgrounds, even amidst the erosion caused by population growth, globalization, and homogenization.

This view reflects the precautionary principle that shows the relationship with creators, people, and the environment when conducting business that must be adhered to. Culture is critical in creating knowledge gained from cultural practice (Arstawa et al., 2020). This condition can be seen in THK's values as organizational culture in Bali. It can directly affect the business's ability internally through organizational learning, teamwork coordination, integration, and externally to respond to the market quickly and adequately. Furthermore, in implementing the palemahan concept, many LPDs in Bali also focus on promoting Bali's sustainable development based on the THK culture by improving environmental sanitation, conservation, and beauty and creating ecological health (Budhiasa \& Riana, 2020). R4 and R5 state that businesses can gain significant recognition from the growing market for sustainable services if they successfully conserve and preserve the environment. Since the concept of sustainable LPD has become a marketing tool, this recognition will also bring financial benefits to traditional villages and local governments. Implement and translate sustainability practices into new businesses within microfinance institutions so that LPDs can compete with other banks in Bali.

Based on the description above, it can be recognized that Palemahan, as one of the cultural factors of THK, has a positive influence on the sustainability of the company's organization to compete in a changing environment. Currently, the environment has changed due to Covid-19, where we must maintain environmental health by paying attention to health protocols. In the context of Parahyangan, Balinese people are obliged to understand the cultural context in their daily lives, such as respecting elemental forces such as air, sky, water, rivers, mountains, plants, viruses, and others, as well as by showing hospitality and cultivating compassion for fellow human beings through various cultural activities or rituals. The parahyangan aspect is related to mental resilience and moral virtue in anticipating daily challenges. During this pandemic, company managers maintain a harmonious relationship with God to achieve a good quality of life. This religious system is reflected in interactions with humans and nature, such as providing services based on honesty, compassion, compassion, kindness, patience, hospitality, generosity, generosity. This activity is called Sewaka (worship), based on prema (divine love). 
Highlighting pawongan in LPD Bali, Respondents 6, 7, 8 stated that:

To create harmony in the social environment (pawongan), behavioral guidelines and work ethics must be formed based on joy and sadness. By practicing these guidelines, people can live in harmony and help each other carry out their duties and responsibilities successfully. For example, superiors can assign tasks to their subordinates because it is their duty. In return, assistants should not consider the assigned tasks as personal duties but as duties imposed by the organization.

THK's philosophy greatly influences the values, attitudes, and social norms in the Balinese business system. This moral obligation and deep connection with the natural environment are firmly anchored in this belief system. This condition was confirmed by R8, who stated: Since the establishment of the LPD in 1984, the community has never experienced conflict with the LPD manager. Many benefits have been received by people, such as employing people in the surrounding villages. Most of all, the expansion of the LPD does not damage the environment that people believe is a sacred place of spiritual life. Research results have proven that values and beliefs do not automatically translate into responsible behavior (Hofenk et al., 2019). Values and attitudes are only two of the many factors that influence actual behavior. Thus, our results do not suggest that philosophy creates responsible expression in microfinance institutions. Bali's LPD development journey is unsustainable, many are not operating, and THK's philosophy has not prevented this from happening. Bali is currently facing serious economic, social, water shortages, water inequity, widespread sewage pollution, and biodiversity and habitat loss. (Kerr \& Wardana, 2019). The number of tourists that continue to increase has not significantly maintained the sustainability of the LPD and is even more damaging (Adityanandana \& Gerber, 2019). Therefore, significant behavioral changes must occur immediately to avoid the worst effects of the COVID-19 pandemic.

In this regard, the THK culture emphasizes that all relationships should be based on pure intentions, truthfulness, and a sense of responsibility. It can only be realized if everyone in the organization has the same insight and vision. Changes in the organization's strategic thinking will question the organization's resource portfolio and how the organization adapts to stakeholders' requirements. Therefore, organizations must apply their dynamic capabilities to increase or even update their resource base. LPDs are urged to reconsider the results of their innovations (Riana et al., 2019), namely procedures for building new competencies and resources as a means of revitalizing the value of THK. This revitalization needs to integrate economic, environmental, social, cultural, time, and interactions between them. These findings contribute to effective international management in helping partners, managers, and employees appreciate the variety of Indonesians, especially Balinese people, in working together as well as the expectations they have for their leaders.

Furthermore, since most management theories have a western outlook, Indonesians cannot assume that management and organizational applications currently prevailing in other parts of the world have universal value or application. Therefore, contextual application and adaptation of Corporate Sustainability (CS) are required to address current sustainable management initiatives. Especially in these difficult times, management that comes from oneself must be easier to implement. LPD currently has an orientation towards the welfare of rural communities who adhere to western management; of course, it cannot be applied in solving credit problems, which are currently largely unpaid. THK's approach to cultural values encourages to give color to the company's sustainability management.

\section{Conclusions}

The Tri Hita Karana culture is in harmony with sustainability, namely Parahyangan, Pawongan, and Palemahan, which considers the harmony between humans and God, humans and sincere humans and the environment. However, we think that the culture of business organizations in Bali has not significantly influenced their performance. This is because the local valuebased culture lies in the domain of values, not in charity actions, so THK-based culture is not enough to directly affect the sustainability of microfinance institutions in Bali. THK values need to be transformed into strategies and action plans to make them able to bring financial benefits to LPD and develop the Village. To bring THK culture into the action domain, a leadership role is needed. Thus, this study introduces a new Corporate Sustainability model by integrating the local West model and a specific reference model for a unique Balinese cultural identity. The field study was successful because of the politeness of one of the cultures. Unfortunately, such politeness causes problems. Like other ethnographic studies, this research is not free from data credibility issues. Although interviewees have the freedom to express their views and their names are not mentioned in this report, it is possible that they may provide information about the company in a favorable tone. This, of course, may result in subjective findings that may not reflect the actual description of the phenomenon under investigation. Further studies are recommended to expand the sample to areas outside Bali to generate a generalization of the findings.

\section{Acknowledgements}

The success of this research is inseparable from the support of various parties such as the Indonesian government, bali local government, indigenous leaders, and LPD leaders both in material and non-material form. All that we say a lot of thanks.

\section{References}

[1] Adityanandana, M., \& Gerber, J. F. (2019). Post-growth in the tropics? Contestations over Tri Hita Karana and a tourism megaproject in Bali. Journal of Sustainable Tourism, 27(12), 1839-1856. https://doi.org/10.1080/09669582.2019.1666857

[2] Akhtar, P. (2019). Drivers of Green Supply Chain Initiatives and their Impact on Economic Performance of Firms: Evidence from Pakistan's Manufacturing Sector. Journal of Competitiveness, 11(2), 5-18. DOI: https:// doi.org/10.7441/joc.2019.03.01

[3] Álvarez Jaramillo, J., Zartha Sossa, J. W., \& Orozco Mendoza, G. L. (2019). Barriers to sustainability for small and medium enterprises in the framework of sustainable developmentLiterature review. Business Strategy and the Environment, 28(4), 512-524. DOI : https://doi.org/10.1002/bse.2261

[4] Ashrafi, M., Magnan, G. M., Adams, M., \& Walker, T. R. (2020). Understanding the Conceptual Evolutionary Path and Theoretical Underpinnings of Corporate Social Responsibility and Corporate Sustainability. Sustainability, 12(3), 760-772.

DOI: https://doi.org/10.3390/su12030760

[5] Astawa, I. P.; Sukawati, T. G. R.; Sugiartha, I. N. G. (2019). Developing A Harmonious Culture Based Sustainable Event Model In Bali Tourism Village. GeoJournal of Tourism and Geosites, 25(2), 446-462. DOI: 10.30892/gtg.25214-372

[6] Astawa, I. P., Sukawati, T. G. R., \& Dwiatmadja, C. (2020). Credit risk management based on harmonious cultural values to support microfinance institution performance in Indonesia. Business: Theory and Practice, 21(1), 340-347. DOI: https://doi.org/10.3846/btp.2020.9945

[7] Barney, J. B. (1991). Firm resources and sustained competitive advantage. Journal of Management, 17, 99-120. DOI: 
https://doi.org/10.1177/014920639101700108

[8] Bartok, O. (2018). The Use of CSR in E-Commerce as a Way to Compete. Journal of Competitiveness, 10(4), 5-20.

DOI: $\quad$ https://doi.org/10.7441/joc.2018.04.01

[9] Bongini, P., Cucinelli, D., Di Battista, M. L., \& Nieri, L. (2019). Profitability shocks and recovery in time of crisis evidence from European banks. Finance Research Letters, 30, 233-239. DOI: https://doi.org/10.1016/j.frl.2018.10.003

[10] Bracalente, B., Chirieleison, C., Cossignani, M., Ferrucci, L., Gigliotti, M., Giovanna Ranalli, M. 2011. The economic impact of cultural events: The Umbria Jazz music festival. Tourism Economics, 17(6), 1235-1255. DOI: https://doi.org/10.5367/te.2011.0096

[11] Broccardo, L., Truant, E., \&Zicari, A. (2019). Internal corporate sustainability drivers: What evidence from family firms? A literature review and research agenda. Corporate Social Responsibility and Environmental Management, 26(1), 1-18. DOI: https://doi.org/10.1002/csr.1672

[12] Buckley, R. (2012). Sustainable tourism: Research and reality. Annals of Tourism Research,39(2): 528-546. DOI: https://doi.org/10.1016/j.annals.2012.02.003

[13] Budhiasa, I. G. S., \& Riana, I. G. (2020). Managing Local Community Participation to Foster Sustainable Tourism Development, the Case of Bali Destination, Indonesia. Journal of Engineering and Applied Sciences, 15(1), 291-298. DOI: 10.36478/jeasci.2020.291.298

[14] Chong, K. L. (2020). The side effects of mass tourism: the voices of Bali islanders. Asia Pacific Journal of Tourism Research, 25(2), 157-169. DOI: https://doi.org/10.1080/10941665.2019.1683591

[15] Civelek, M., Ključnikov, A., Krajčík, V., Žufan, J. (2019). The Importance of Discount Rate and Trustfulness of A Local Currency for the Development of Local Tourism. Journal of Tourism and Services, 10(19), 77-92. DOI: https://doi.org/10.29036/jots.v10i19.117

[16] CRESWELL, John W.; CLARK, Vicki L. Plano. Designing and conducting mixed methods research. Sage publications, 2017. DOI: https://doc1.bibliothek.li/acd/FLMF050277.pdf

[17] Das, M., Rangarajan, K., \& Dutta, G. (2020). Corporate sustainability in SMEs: an Asian perspective. Journal of Asia Business Studies, 14, 109-138.

https://www.emerald.com/insight/content/doi/10.1108/JABS-102017-0176/full/html

[18] Demirel, P., \& Kesidou, E. (2019). Sustainability-oriented capabilities for eco-innovation: Meeting the regulatory, technology, and market demands. Business Strategy and the Environment, 28(5), 847-857.

DOI: https://doi.org/10.1002/bse.2286

[19] Garry, T., \& Harwood, T. (2017). Exploring Consumer Associations Between Corporate Reputation, Corporate Sustainability, and Product Attributes Within Utilitarian Market Contexts. International Studies of Management \& Organization, 47(3), 258-275.

DOI: https://doi.org/10.1080/00208825.2017.1318021

[20] Hofenk, D., van Birgelen, M., Bloemer, J., \& Semeijn, J. (2019). How and when retailers' sustainability efforts translate into positive consumer responses: the interplay between personal and social factors. Journal of Business Ethics, 156(2), 473-492. https://link.springer.com/article/10.1007/s10551-017-3616-1

[21] Hofstede, G. (2007). A European in Asia. Asian Journal of Social Psychology, 10(1), 16-21. DOI: https://doi.org/10.1111/j.1467839X.2006.00206.x

[22] Joseph, L., Jun, B. M., Jang, M., Park, C. M., Muñoz-Senmache, J. C., Hernández-Maldonado, A. J., ... \& Yoon, Y. (2019). Removal of contaminants of emerging concern by metal-organic framework nanoadsorbents: A review. Chemical Engineering Journal, 369, 928-946. https://doi.org/10.1016/j.cej.2019.03.173

[23] Jovchelovitch, S. (2019). Knowledge in context: Representations, community and culture. Routledge. DOI: https://doi.org/10.4324/9781315173368

[24] Kerr, T., \&Wardana, A. (2019). Utopian resort living: islands of reclamation and environmental resistance in Bali and Western Australia. Journal of Tourism and Cultural Change, 1 (14), 345360. DOI: https://doi.org/10.1080/14766825.2019.1694534

[25] Khan, S. A. R., \& Yu, Z. (2020). Introductory Chapter: The Outbreak of Coronavirus (COVID-19)-Death and Terror in 2020. In Terrorism and Developing Countries. IntechOpen. IntechOpen, DOI: 10.5772/intechopen.91955. Available from: https://www.intechopen.com/books/terrorism-and-developingcountries/introductory-chapter-theoutbreak-of-coronavir

[26] Kompas. (2020). Kebijakan-jokowi-tangani-covid-19-gratiskantarif-listrik- hingga?. 2020 (Internet). Available from :https://www.kompas.com/tren/read/2020/04/01/160000765/5kebijakan-jokowi-tangani-covid-19-gratiskan-tarif-listrikhingga?page=all [Accessed: 2020-06-26]

[27] Lozano, R. (2019). Analysing the use of tools, initiatives, and approaches to promote sustainability in corporations. Corporate Social Responsibility and Environmental Management, 27, 982998. DOI: https://doi.org/10.1002/csr.1860

[28] Mahoney, Joseph T., and J. Rajendran Pandian.(1992). The resource-based view within the conversation of strategic management. Strategic management journal, 13(5), 363-380. DOI: https://doi.org/10.1002/smj.4250130505

[29] Manning, B., Braam, G., \&Reimsbach, D. (2019). Corporate governance and sustainable business conduct-Effects of board monitoring effectiveness and stakeholder engagement on corporate sustainability performance and disclosure choices. Corporate Social Responsibility and Environmental Management, 26(2), 351-366. DOI: https://doi.org/10.1002/csr.1687

[30] Noreen, U. (2020). The Estimation of Risk Management Efficiency and its Determinants. Jurnal Ekonomi Malaysia, 54(1), 69-79.DOI: http://dx.doi.org/10.17576/JEM-2020-5401-5

[31] Obal, M., Morgan, T., \& Joseph, G. (2020). Integrating sustainability into new product development: The role of organizational leadership and culture. Journal of Small Business Strategy, 30(1), 43-57. https://libjournals.mtsu.edu/index.php/jsbs/article/view/1664

[32] Pitelis Christon N. A . (2007). Behavioral Resource-Based View of the Firm: The Synergy of Cyert and March (1963) and Penrose (1959). Organization Science, 18, 67-89. DOI: https://doi.org/10.1287/orsc.1060.0244

[33] Plaček, M., Půček, M., Ochrana, F., Křápek, M., \& Matyáš, O.H. (2019). Risk Management for Cultural Organizations. The Example of Agricultural Museums in the Czech Republic. Cultural Management: Science and Education, 3(2), 111-122. DOI:10.30819/cmse.3-2.07

[34] Porter, M. E. (1985). Technology and competitive advantage. The Journal of Business Strategy, 5(3), 60-72. https://www.hbs.edu/faculty/Pages/item.aspx?num $=4324$

[35] Radar Bali. (2021). Pandemic Does Not Affect LPD Business in Bali, Assets 2020 Through 23.6 trillion. Available from: https://radarbali.jawapos.com/read/2021/02/12/241036/pandemi -tak-pengaruhi-bisnis-Ipd-di-bali-aset-2020-tembus-rp-236-t. [Accessed: 2021-06-26]

[36] Rahmawati, P. I., Jiang, M., \& DeLacy, T. (2019). Framework for stakeholder collaboration in harnessing corporate social responsibility implementation in tourist destination to build community adaptive capacity to climate change. Corporate Social Responsibility and Environmental Management, 26(6), 1261-1271. DOI: https://doi.org/10.1002/csr.1745

[37] Rajiani, I., \& Pypłacz, P. (2018). National culture as modality in managing the carbon economy in Southeast Asia. Polish Journal of Management Studies, 18, 296-310.

http://yadda.icm.edu.pl/yadda/element/bwmeta1.element.baztec h-2d457750-1a54-4aed-8b29-6f0f84b508e5

[38] Rajiani, I., \& Kot, S. (2018). The prospective consumers of the Indonesian green aviation initiative for sustainable development 
in air transportation. Sustainability, 10(6), 1772.

DOI: https://doi.org/10.3390/su10061772

[39] Ranasinghe, R. (2019). Antecedents of Job Performance of Tourism Graduates: Evidence from State University-Graduated Employees in Sri Lanka.Journal of Tourism and Services, 10(18), 16-34.

https://papers.ssrn.com/sol3/papers.cfm?abstract id $=3517673$

[40] Reicher, Z.R. (2019). Opportunities for small and medium sized enterprises in the field of corporate social responsibility.Ekonomicko-manazerske Spektrum, 13(1), 26-37. https://www.ceeol.com/search/article-detail?id=782338

[41] Riana, I. G., Rihayana, I. G., Ratih, K., \& Dewi, I. A. (2019). Creating innovation through knowledge sharing and absorptive capacity. Polish Journal of Management Studies, 19, 338-352. DOI: 10.17512/pjms.2019.19.1.26

[42] Ritchie, J., Lewis, J., \& McNaughton, N. C. \&Ormston, R.(2013). Qualitative Research Practice: A Guide for Social Science Students and researchers, London: SAGE Publications. https://uk.sagepub.com/en-gb/eur/home

[43] Sampson, H., \&Johannessen, I. A. (2020). Turning on the tap: the benefits of using 'real-life'vignettes in qualitative research interviews. Qualitative Research, 20(1), 56-72.

DOI: https://doi.org/10.1177/1468794118816618

[44] Schaltegger, S., \& Burritt, R. (2018). Business cases and corporate engagement with sustainability: Differentiating ethical motivations. Journal of Business Ethics, 147(2), 241-259. https://link.springer.com/article/10.1007/s10551-015-2938-0

[45] Schönborn, G., Berlin, C., Pinzone, M., Hanisch, C., Georgoulias, K., \&Lanz, M. (2019). Why social sustainability counts: The impact of corporate social sustainability culture on financial success. Sustainable Production and Consumption, 17, 1-10. DOI: https://doi.org/10.1016/j.spc.2018.08.008

[46] Soderstrom, S. B., \& Weber, K. (2020). Organizational structure from interaction: Evidence from corporate sustainability efforts. Administrative Science Quarterly, 65(1), 226-271. DOI: https://doi.org/10.1177/0001839219836670

[47] Stonehouse, G.; Snowdon, B. (2007). Competitive advantage revisited: Michael Porter on strategy and competitiveness. Journal of Management Inquiry, 16(3), 256-273. DOI: https://doi.org/10.1177/1056492607306333

[48] Sukawati, T. G. R., Riana, I. G., Rajiani, I., \& Abbas, E. W. (2020). Managing corporate sustainability by revitalizing Balinese cultural identity. Polish Journal of Management Studies, 21(1), 382-392. DOI 10.17512/pjms.2020.21.1.28

[49] Sukawati, T. G. R., \& Astawa, I. P. (2017). Improving performance by harmonious culture approach in internal marketing. Polish Journal of Management Studies, 16, 226-223. DOI 10.17512/pjms.2017.16.1.19
[50] Tempo. (2020). This is why Bali will be favored after pandemic Covid-19 [Internet]. Available from: https://travel.tempo.co/read/1348693/ini-alasan-bali-bakaldigemari-usai-pandemi-covid-19 [Accessed: 2020-06-26]

[51] Thakur, V., \&Mangla, S. K. (2019). Change management for sustainability: Evaluating the role of human, operational and technological factors in leading Indian firms in home appliances sector. Journal of cleaner production, 213, 847-862. DOI: https://doi.org/10.1016/j.jclepro.2018.12.201

[52] Tian, X., \& Christensen, T. (2020). Myths, instrumental reality, or cultural change? Modern service-oriented government reforms in China. International Public Management Journal, 1-18. DOI: https://doi.org/10.1080/10967494.2019.1710311

[53] Van den Berg, J., Zijp, M. C., Vermeulen, W. J., \& Witjes, S. (2019). Identifying change agent types and its implications for corporate sustainability integration based on worldviews and contextual factors. Journal of Cleaner Production, 229, 11251138 .

DOI: https://doi.org/10.1016/j.jclepro.2019.04.272

[54] Wakimin, N. F., Azlina, A. A., Samsudin, H., \& Kamaludin, M. (2019). The Impact of Tourism Demand, Government Expenditure on Education and Income on the Environment in ASEAN-5 Countries (Kesan Permintaan Pelancongan, Perbelanjaan Kerajaan Ke Atas Pendidikan Dan Pendapatan Terhadap Alam Sekitar Di Negara-Negara ASEAN-5). Jurnal Ekonomi Malaysia, 53(3),75- 90. DOI: https://dx.doi.org/10.17576/JEM-2019-5303-06

[55] Wróblewski, Ł., Dacko-Pikiewicz, Z. (2018). Sustainable Consumer Behaviour in the Market of Cultural Services in Central European Countries: The Example of Poland. Sustainability, 10, 38-56. DOI: https://doi.org/10.3390/su10113856

[56] Wróblewski, Ł., Kasperek, A. (2019). Euroregion as an Entity Stimulating the Sustainable Development of the Cross-Border Market for Cultural Services in a City Divided by a Border. Sustainability, 11 , DOI:https://doi.org/10.3390/su11082232

[57] Yuan Pan,S.,Gao M.,Kim H.,Shah K.J.,Lu Pei S.,Chi Chiang P. (2018). Advance and Challenges in Sustainable Tourism Towards a Green Economy. Science of The Environment. 635, 452-469. DOI: https://doi.org/10.1016/j.scitotenv.2018.04.134

[58] Zahid, M., Rahman, H. U., Muneer, S., Butt, B. Z., Isah-Chikaji, A., \&Memon, M. A. (2019). Nexus between government initiatives, integrated strategies, internal factors and corporate sustainability practices in Malaysia. Journal of Cleaner $\begin{array}{lll}\text { Production, } & 241, & 118329 .\end{array}$ https://doi.org/10.1016/j.jclepro.2019.118329

[59] Zhulega, I.A., Gagulina, N.L., Samoylov, A.V., \& Novikov, A.V. (2019). Problems of corporate economics and sustainable development in the context of the sanction world order: Living standards and live quality, Ekonomicko-manazerske spektrum, 13(1), 83-95.

https://www.ceeol.com/search/article-detail?id=782349 